\title{
Does banking relationship configuration affect the risk-taking behavior of French SMEs?
}

\author{
Ludovic Vigneron ${ }^{1, *} \bullet$ Ramzi Benkraiem² \\ ${ }^{1}$ Université de Valenciennes et du Hainaut-Cambrésis, Famars, France \\ ${ }^{2}$ Audencia Business School, Nantes, France
}

Received: 5 September 2015

Revised: 12 November 2015

Accepted: 24 November 2015

\begin{abstract}
Using a new and unique dataset dealing with French small and medium-sized enterprise (SME) financing that provides detailed information about 1116 firm-bank relationships, we test how the number of banks with which a firm works and the organizational structure of its main bank influence its risk-taking behavior. We find evidence that SMEs engaged with a decentralized main bank (a local or mutual one) invest in less risky projects, especially when they work with fewer than three banks (one or two). We also find evidence that single-bank SMEs engaged with a centralized bank (a large or foreign one) take significantly more risks than the others.
\end{abstract}

Keywords: bank relationships, risk-taking behavior, SMEs

JEL Classification Codes: G21, G32, L26, M21

\section{Introduction}

Banks may influence small and medium-sized enterprise (SME) investment decisions through their screening and monitoring skills (Benkraiem, 2014). Corporate managers have incentives to adapt their risk-taking behavior to bank preferences in order to obtain new credit or to secure credit renewal (Acharya et al., 2011; Bennardo et al., 2015). The strength of these incentives depends particularly on the importance of bank loans in a firm funding, the number of bank lenders with which the firm is engaged, the contribution of each bank to total borrowing, and the ability of every bank to deal with asymmetric information (Fluet and Garellea, 2014).

We build upon this reasoning to investigate how the configuration of banking relationships affects the risk-taking behavior of SMEs in a European context, i.e. France. As in several continental European countries, France typically relies on a bank-centered financial system. The context is consequently interesting to study banking relationships. In this article, we

\footnotetext{
* Corresponding author. E-mail: ludovic.vigneron@univ-valenciennes.fr.

Citation: Vigneron, L. and Benkraiem, R. (2015) Does banking relationship configuration affect the risk-taking behavior of French SMEs?, Economics and Business Letters, 4(4), 166-174.
} 
particularly shed light on two dimensions of banking relationship configuration: the number of banks with which a firm deals and the main bank organizational structure.

A large number of bank lenders for a particular firm is likely to generate free-riding problems in monitoring SMEs. In this situation, bank coordination is difficult to achieve and a lack of coordination reduces the effectiveness of joined-bank monitoring (Boot, 2000; Carletti, 2004; Bris and Welsh, 2005). Consequently, ineffective monitoring may encourage corporate managers to engage in high-risk decisions. In this context, the likelihood of either very good or very bad actions is high. This is expected to result in a high variability of firm performance.

The organizational structure of a firm main bank, i.e. decentralized (local or mutual) or centralized (national or international), may affect the influence of banking relationships on a firm risk-taking behavior. In particular, lending by a decentralized main bank reduces asymmetric information problems between fund providers and business customers. In other words, this dimension of banking relationship configuration lowers the main bank monitoring costs. It also facilitates a bank influence on a firm investment decisions. A high level of decentralized bank loans is expected to cause a low variability in firm performance.

Hence, the research hypotheses concern concrete differences in the influence of the configuration of banking relationships on the variability of firm performance. High risk-taking behavior generates a high variability of firm performance and vice versa. The empirical findings show that for firms engaging a small number of bank lenders, bank monitoring abilities are improved and low risk-taking behavior is fostered, i.e. a low variability in firm performance. Furthermore, they reveal that a high level of decentralized bank loans in total borrowing favors low risk-taking behavior if the firm works with fewer than three banks.

This paper contributes to the literature by allowing a better understanding of the influence of banking relationship configuration on the risk-taking behavior of SMEs, specifically. SMEs are key actors in value creation and economic growth support. According to recent statistics from the French government, these companies create more than $66 \%$ of private sector employment and generate $50 \%$ of the added value. Consequently, this research should be of particular interest to researchers, fund providers and managers of SMEs.

The article proceeds as follows. Section 2 discusses the methodology, section 3 describes the empirical findings and section 4 provides the conclusion.

\section{Methodology}

\subsection{Regressions specifications}

The research uses Glejser's (1969) heteroskedasticity test to identity relevant factors that influence firm risk-taking behavior. This methodology was used for large firms by Adams et al. (2005) and Boubaker et al. (2012). It consists of measuring firm performance deviation from its expected value. High risk-taking behavior generates a high volatility of firm performance and vice versa. Consequently, positive or negative abnormal performances are expected to be particularly important indicators of firms with high risk-taking behavior.

To implement this method, we first had to estimate a model of normal firm performance. In the SME context, we cannot use predicted returns extracted from a stock market model or Tobin's Q, as in previous studies, because most of these firms are not listed. We can only consider operating performance through return on assets (ROA). We estimated a model similar to those of Morck et al. (1988), Yermarck (1996), Himmelberg et al. (1999) and Cheng (2008). In addition to banking relationships, we included corporate, diversification and governance factors as control variables. Hence, the specification is as follows: 


$$
\begin{aligned}
\text { ROA }_{i, t}=\alpha+ & \beta_{1} \text { Banking Relationships }_{i, t} \\
& +\beta_{2} \text { Corporate Financial Characteristics } \\
& +\beta_{6} \text { Geographical Diversification }_{i, t} \\
& +\beta_{7} \text { Corporate Governance }_{i, t}+\beta_{8} \text { Industries }_{i}+\beta_{9} \text { Years }_{t}+\varepsilon_{i, t}
\end{aligned}
$$

Once the normal performance model was estimated, we conducted a Glejser test. We ran a model of residuals which represent abnormal firm performances. Thus, we deployed a regression of the absolute values of these residuals, as follows:

$$
\begin{aligned}
\left|\varepsilon_{i, t}\right|=\alpha+ & \beta_{1} \text { Banking Relationships }_{i, t}+\text { Corporate Financial Characteristics } \\
& +\beta_{6} \text { Geographical Diversification }_{i, t} \\
& +\beta_{7} \text { Corporate Governance }_{i, t}+\beta_{8} \text { Industries }_{i}+\beta_{9} \text { Years }_{t}+\epsilon_{i, t}
\end{aligned}
$$

ROA is computed by dividing operating earnings by total assets. The data collected on banking relationships contains information about the names of firm main and secondary banks. We counted the number of lending banks for each firm. We defined a dummy variable called the "decentralized main bank", which is equal to 1 if the main bank is a local or mutual bank and 0 otherwise. For our control variables, we used corporate financial characteristics, geographical diversification indicators and corporate governance variables. We also considered year and industry fixed effects. The corporate financial characteristics were the same as those of Morck et al. (1988), Adams et al. (2005) and Cheng (2008). Firm size is a natural logarithm of total assets; age is a natural logarithm of firm age; leverage is total debt divided by total assets and growth opportunities are a natural logarithm of capital expenditures over total sales. Geographical diversification was estimated through the number of firm secondary sites and the export ratio calculated as exports over total sales. Corporate governance variables were adapted to the SME context. To do so, we used four dummy variables. The first variable takes the value 1 if the firm is a family business. The second variable takes the value 1 if the firm is managed by a female corporate manager. The third variable takes the value of 1 if the company is an incorporated business. The fourth variable takes the value 1 if the firm is part of a group. Definitions and expected signs are summarized in Appendix A.

\subsection{Data}

The sample used in this research is composed of SMEs for which it was possible to identify the main bank from the DIANE database ${ }^{1}$ and secondary banks from the Kompass Europe ${ }^{2}$ database in 2010. This year can be considered as a normal and representative period for bank relationships. It is two years after the bank crisis and there is no major institutional change for SME finance during this lapse of time ${ }^{3}$. From DIANE, we identified 6908 firm-main bank relationships. We obtained full information about banking relationships from Kompass Europe for 1145 firms. We then excluded firms that do not meet the European Commission criteria for SMEs. Hence, the final sample consisted of data for 1116 firms observed between 2004 and 2012. Half of these SMEs operate in the manufacturing sector, $23 \%$ in retailing, $9 \%$ in building, $5 \%$ in transport and the remaining ones in various other service sectors. On average, the

\footnotetext{
${ }^{1}$ DIANE is a financial database covering all firms registered in France, in particular SMEs. DIANE is managed by the Bureau van Dijk. This database is available on the following link: https://diane.bvdinfo.com/.

${ }^{2}$ Kompass Europe is a commercial directory of firms which mainly includes product and limited banking information. This database is available on the following link: http://fr.kompass.com/.

${ }^{3}$ Basel III capital requirements for banks have been voted in December 2010 but the implementation is scheduled for March 2019.
} 
sampled SMEs have 39 employees, generate a turnover of 10 million euros and display total assets of 15 million euros.

Table 1. Descriptive statistics.

\begin{tabular}{lrrrrr}
\hline \hline Variable & $\begin{array}{r}\text { Number of } \\
\text { observations }\end{array}$ & Mean & $\begin{array}{r}\text { Standard } \\
\text { deviation }\end{array}$ & Minimum & Maximum \\
\hline ROA & 9687 & 7.442 & 9.553 & -23.124 & 35.351 \\
St. dev. of ROA & 1115 & 5.925 & 3.567 & 0.175 & 24.178 \\
\hline \hline Banking relationships: & & & & & \\
\hline Number of banks & 1116 & 1.908 & 1.052 & 1 & 7 \\
One bank & 1116 & 0.448 & - & 0 & 1 \\
Decentralized main bank & 1116 & 0.685 & - & 0 & 1 \\
\hline \hline Corporate financial characteristics: & & & & & \\
\hline Size & 9487 & 8.208 & 0.984 & 5.703 & 16.534 \\
Age & 9487 & 3.244 & 0.566 & 1.349 & 4.678 \\
Leverage & 9487 & 58.653 & 20.040 & 12.216 & 112.829 \\
Growth opportunities & 7933 & 0.772 & 1.228 & -2.695 & 3.690 \\
\hline \hline Geographical diversification: & & & & & \\
\hline Export & 9481 & 11.274 & 20.158 & 0 & 91.626 \\
Nb. of sec. sites & 1116 & 1.300 & 3.687 & 0 & 50 \\
\hline \hline Corporate governance: & & & & & \\
\hline Family business & 1116 & 0.416 & - & 0 & 1 \\
Female CEO & 1116 & 0.076 & - & 0 & 1 \\
Incorporated Business & 1116 & 0.778 & - & 0 & 1 \\
Subsidiary & 1116 & 0.326 & - & 0 & 1 \\
\hline \hline
\end{tabular}

\section{Empirical findings}

Table 1 presents the descriptive statistics. The average number of bank lenders for each sampled firm is 1.9 . About $45 \%$ of the firms are engaged with only one main bank. The maximum number of banks is seven (this case concerns only one firm; we considered this firm as an outlier and excluded it from the analysis). $68.5 \%$ of SMEs have a decentralized main bank. $41 \%$ of sampled firms are family businesses, only $7.6 \%$ are managed by a woman, $77 \%$ are corporations, and $32 \%$ belong to a group.

Table 2 reports the regression analyses. The results in column 1 suggest that risk-taking decreases both with a firm working with a decentralized main bank and the number of banks with which it deals. Banks which are more efficient at providing banking relationship can push a firm to be more careful in its investment policy but dealing with multiple banks can produce the same kind of effect. We also notice that the interaction term between the two variables is positive but not significant. The effect of the number of banks on the abnormal variability of ROA does not depend on the main bank type.

To complement these results, the bank relationship variables in column 2 were substituted with a dummy variable, taking the value 1 if the firm works only with one bank which has a decentralized structure and 0 otherwise. The new variable is not significantly related to firm risk-taking. The same substitution was made in column 3 in order to consider firms which work with only one centralized bank. The results show clearly that those firms take significantly more risk than the others. The weak monitoring activity of a bank engaged in transactional banking appears to allow more risk-taking. In column 4, the model for an SME working with only one 
bank is estimated and the fact that this bank is a decentralized one is used as a test variable. The dummy is negative and highly significant.

Table 2. Absolute value of ROA residuals regressions.

\begin{tabular}{|c|c|c|c|c|c|c|}
\hline & $(1)$ & $(2)$ & $(3)$ & $(4)$ & $\overline{(5)}$ & (6) \\
\hline Constant & $\begin{array}{r}15.869 * * * \\
(18.730) \\
\end{array}$ & $\begin{array}{r}14.698^{* * * *} \\
(18.000) \\
\end{array}$ & $\begin{array}{r}14.667 * * * \\
(18.330) \\
\end{array}$ & $\begin{array}{r}14.758^{* * * *} \\
(11.660) \\
\end{array}$ & $\begin{array}{r}15.371 * * * \\
(15.410) \\
\end{array}$ & $\begin{array}{r}14.687 * * * \\
(8.620) \\
\end{array}$ \\
\hline $\mathrm{Nb}$. of banks & $\begin{array}{r}-0.223 * * \\
(2.140)\end{array}$ & & & & & \\
\hline Decent. main bank & $\begin{array}{r}-1.057 * * * \\
(3.520) \\
\end{array}$ & & & $\begin{array}{r}-0.495 * * \\
(2.030) \\
\end{array}$ & $\begin{array}{r}-1.007 * * * \\
(5.550) \\
\end{array}$ & $\begin{array}{r}0.213 \\
(0.660) \\
\end{array}$ \\
\hline $\begin{array}{l}\text { Nb. of banks } \times \\
\text { Decent. main bank }\end{array}$ & $\begin{array}{r}0.196 \\
(1.540)\end{array}$ & & & & & \\
\hline One decent. bank & & $\begin{array}{r}-0.055 \\
(0.380)\end{array}$ & & & & \\
\hline One cent. bank & & & $\begin{array}{r}0.448 * * \\
(2.160) \\
\end{array}$ & & & \\
\hline Size & $\begin{array}{r}-0.833 * * * \\
(9.740)\end{array}$ & $\begin{array}{r}-0.798 * * * \\
(9.410)\end{array}$ & $\begin{array}{r}-0.809 * * * \\
(9.580)\end{array}$ & $\begin{array}{r}-0.601 * * * \\
(4.790)\end{array}$ & $\begin{array}{r}-0.699 * * * \\
(6.850)\end{array}$ & $\begin{array}{r}-1.273 * * * \\
(7.950)\end{array}$ \\
\hline Age & $\begin{array}{r}-0.363 * * * \\
(3.070) \\
\end{array}$ & $\begin{array}{r}-0.354 * * * \\
(3.010) \\
\end{array}$ & $\begin{array}{r}-0.353 * * * \\
(3.010) \\
\end{array}$ & $\begin{array}{r}-0.544 * * * \\
(3.210)\end{array}$ & $\begin{array}{r}-0.463^{* * *} \\
(3.440)\end{array}$ & $\begin{array}{r}0.226 \\
(0.820)\end{array}$ \\
\hline Leverage & $\begin{array}{r}-0.025 * * * \\
(6.200) \\
\end{array}$ & $\begin{array}{r}-0.026 * * * \\
(6.400) \\
\end{array}$ & $\begin{array}{r}-0.025^{* * * *} \\
(6.240) \\
\end{array}$ & $\begin{array}{r}-0.028 * * * \\
(4.490)\end{array}$ & $\begin{array}{r}-0.024 * * * \\
(5.260)\end{array}$ & $\begin{array}{r}-0.027 * * * \\
(3.250) \\
\end{array}$ \\
\hline Growth opp. & $\begin{array}{r}0.083 \\
(1.470) \\
\end{array}$ & $\begin{array}{r}0.083 \\
(1.470) \\
\end{array}$ & $\begin{array}{r}0.086 \\
(1.520) \\
\end{array}$ & $\begin{array}{r}0.011 \\
(0.086) \\
\end{array}$ & $\begin{array}{r}0.039 \\
(0.066) \\
\end{array}$ & $\begin{array}{r}0.345^{* * * *} \\
(2.980) \\
\end{array}$ \\
\hline Export & $\begin{array}{r}0.009 * * \\
(2.560) \\
\end{array}$ & $\begin{array}{r}0.010 * * * \\
(2.790) \\
\end{array}$ & $\begin{array}{r}0.009 * * * * \\
(2.690) \\
\end{array}$ & $\begin{array}{r}0.016 * * * \\
(3.140) \\
\end{array}$ & $\begin{array}{r}0.011 * * * \\
(2.620) \\
\end{array}$ & $\begin{array}{r}0.007 \\
(1.060) \\
\end{array}$ \\
\hline Number of sites & $\begin{array}{r}-0.049 * * * \\
(3.250) \\
\end{array}$ & $\begin{array}{r}-0.058^{* * * *} \\
(3.940) \\
\end{array}$ & $\begin{array}{r}-0.056^{* * * *} \\
(3.780) \\
\end{array}$ & $\begin{array}{r}-0.148 * * * \\
(5.880) \\
\end{array}$ & $\begin{array}{r}-0.111 \\
(6.620)\end{array}$ & $\begin{array}{r}0.000 \\
(0.020) \\
\end{array}$ \\
\hline Family business & $\begin{array}{r}-0.259^{*} \\
(1.760) \\
\end{array}$ & $\begin{array}{r}-0.290 * * \\
(1.970) \\
\end{array}$ & $\begin{array}{r}-0.286^{*} \\
(1.940) \\
\end{array}$ & $\begin{array}{r}-0.076 \\
(0.320) \\
\end{array}$ & $\begin{array}{r}-0.580 \\
(3.310) \\
\end{array}$ & $\begin{array}{l}0.566^{*} \\
(1.940) \\
\end{array}$ \\
\hline Female manager & $\begin{array}{r}-0.234 \\
(0.960)\end{array}$ & $\begin{array}{r}-0.160 \\
(0.650)\end{array}$ & $\begin{array}{l}-0.157 \\
(0.640)\end{array}$ & $\begin{array}{r}0.354 \\
(0.790)\end{array}$ & $\begin{array}{r}-0.321 \\
(1.110)\end{array}$ & $\begin{array}{r}0.379 \\
(0.750)\end{array}$ \\
\hline $\begin{array}{l}\text { Incorporated } \\
\text { business }\end{array}$ & $\begin{array}{r}0.591 * * * \\
(3.510) \\
\end{array}$ & $\begin{array}{r}0.607 * * * \\
(3.580) \\
\end{array}$ & $\begin{array}{r}0.621 * * * * \\
(3.710) \\
\end{array}$ & $\begin{array}{r}-0.026 \\
(0.110) \\
\end{array}$ & $\begin{array}{r}0.390 * * * \\
(2.030) \\
\end{array}$ & $\begin{array}{r}1.578 * * * * \\
(4.180) \\
\end{array}$ \\
\hline Subsidiary & $\begin{array}{l}0.305^{*} \\
(1.870)\end{array}$ & $\begin{array}{r}0.346^{* * *} \\
(2.130)\end{array}$ & $\begin{array}{r}0.321^{* *} \\
(1.960)\end{array}$ & $\begin{array}{r}-0.131 \\
(0.520) \\
\end{array}$ & $\begin{array}{r}0.103 \\
(0.530) \\
\end{array}$ & $\begin{array}{r}0.980 * * * * \\
(3.170)\end{array}$ \\
\hline Year fixed effects & Yes & Yes & Yes & Yes & Yes & Yes \\
\hline $\begin{array}{l}\text { Industry fixed } \\
\text { effects }\end{array}$ & Yes & Yes & Yes & Yes & Yes & Yes \\
\hline Fisher test & $14.97 * * *$ & $15.53 * * *$ & $15.78 * * *$ & $12.70 * * *$ & $15.94 * * *$ & $6.16^{* * * *}$ \\
\hline Adj.R2 & 0.055 & 0.051 & 0.052 & 0.078 & 0.056 & 0.091 \\
\hline Nb. obs. & 7924 & 7924 & 8082 & 3586 & 6028 & 1896 \\
\hline
\end{tabular}

Table 2 reports regression estimations of equation 2. In column 1, 2 and 3, we use the full sample. In column 4, we focus on the subgroup of firms working with only one bank. In column 5, we study the subgroup of firms working with fewer than three banks ( 1 or 2 ). In column 6 , we investigate firms working with more than two banks ( 3 and more). Student t-statistics are reported in brackets. $* * *, * *$ and $*$ denote statistical significance at $1 \%, 5 \%$ and $10 \%$, respectively.

In order to deepen the analysis, the sample was split into groups of firms that work with fewer than three banks (i.e. one or two) and those that work with three or more. Equation 2 was estimated for each group using a dummy variable, taking 1 if the main bank is a decentralized 
one and 0 otherwise. For the first group (see column 5), the variable is negative and significant at the level of $1 \%$. For the second one (see column 6), the variable is positive but not significant. Banking relationship seems to be more efficient at reducing SME risk-taking when the decentralized main bank operates only with a limited number of competitors.

The control variables produced the expected signs and are mostly significant in all the analyses and for each different performance measure. Firm size, age, the number of secondary sites that they exploit, and operating as a family business reduce risk-taking. Operating as a corporation, being a subsidiary and having higher export levels increase the risk-taking behavior. Leverage level decreases the abnormal variability of ROA. Being managed by a female CEO has no significant effect. The growth opportunities measured as capital expenditures (CAPEX) over sales are also never significant.

In order to check whether the banking relationship structure increases or decreases both the probability of good and bad decisions for a given firm throughout the studied lapse of time, the standard deviation of ROA between 2004 and 2012 was used as the explanatory variable in equation 2. For the explanatory variables, the mean of their time moving variables (size, age, leverage, growth opportunities, and exports) was used for each firm. The other variables do not involve a time variation.

Following Adams et al. (2005), Cheng (2008) and Boubaker et al. (2012), the new specifications were used as a robustness check for the previous analysis. A positive sign for a coefficient associated with a variable indicates that the related parameter increases a firm performance standard deviation and thus, a firm risk-taking. In contrast, a negative sign shows that the associated factor reduces a firm risk-taking.

The results reported in table 3 are qualitatively similar to those obtained with the Glejser heteroskedasticity test. The only difference relies on the interaction term between the number of banks with which a firm works and the decentralized structure of their main bank. The related coefficient is positive and significant. Multiple banking, once again, appears to reduce risktaking more intensively in a transactional context than in a relational context. Working with one more bank decreases the standard deviation of ROA by 0.380 when the firm works with a centralized main bank (transactional context). However, when a firm works with a decentralized main bank (relational context), the effect is only 0.037. For firms operating with a centralized main bank, working with one more bank decreases the risk by 2.454 , but for those that work with a decentralized bank, the risk increases by 0.251 . The control variables are generally in line with those of the previous analyses. Note that we conducted several additional robustness checks replicating the previous analyses using two other firm performance indicators, namely return on equity and operating cash-flows divided by to total assets. The non-reported results confirm and give more credibility to those previously presented.

\section{Conclusion}

The effect of banking relationship configuration on the risk-taking behavior of SMEs was examined and evidence was found that banking relationship, i.e. the fact of working with a decentralized main bank, reduced firm risk-taking when the firm works with fewer than three banks. Working with a higher number of banks can also have the same type of effect but only if the firm is engaged in transactional banking. The configuration showing higher levels of risktaking is when an SME only works with one bank and that bank has a centralized organizational structure. These findings are in line with the expectation of an efficient monitoring power of relationship banks and an important degree of influence of these banks over their clients in a close banking context. 
Table 3. Standard deviation of ROA.

\begin{tabular}{|c|c|c|c|c|c|c|}
\hline & $\overline{(11)}$ & (2) & (3) & (4) & $\overline{(5)}$ & (6) \\
\hline Constant & $\begin{array}{r}15.396 * * * \\
(10.760)\end{array}$ & $\begin{array}{r}14.320 * * * \\
(10.420)\end{array}$ & $\begin{array}{r}14.095 * * * \\
(10.610)\end{array}$ & $\begin{array}{r}17.430 * * * \\
(7.630) \\
\end{array}$ & $\begin{array}{r}16.438 * * * \\
(9.540) \\
\end{array}$ & $\begin{array}{r}9.535 * * * \\
(3.150) \\
\end{array}$ \\
\hline $\mathrm{Nb}$. of banks & $\begin{array}{r}-0.380 * * \\
(2.190)\end{array}$ & & & & & \\
\hline Decent. main bank & $\begin{array}{r}-1.378 * * * \\
(2.880) \\
\end{array}$ & & & $\begin{array}{r}-1.213 * * * \\
(3.160) \\
\end{array}$ & $\begin{array}{r}-1.055 * * * \\
(3.730) \\
\end{array}$ & $\begin{array}{r}0.053 \\
(0.110) \\
\end{array}$ \\
\hline $\begin{array}{l}\text { Nb. of banks } \times \\
\text { Decent. main bank }\end{array}$ & $\begin{array}{r}0.343^{*} \\
(1.680)\end{array}$ & & & & & \\
\hline $\begin{array}{l}\text { One decentralized } \\
\text { bank }\end{array}$ & & $\begin{array}{r}-0.229 \\
(1.050)\end{array}$ & & & & \\
\hline One centralized bank & & & $\begin{array}{r}0.993 * * \\
(2.930)\end{array}$ & & & \\
\hline Size & $\begin{array}{r}-1.048 * * * \\
(7.430)\end{array}$ & $\begin{array}{r}-1.035^{* * * *} \\
(7.400)\end{array}$ & $\begin{array}{r}-1.054 * * * \\
(7.590)\end{array}$ & $\begin{array}{r}-1.109 * * * \\
(4.790)\end{array}$ & $\begin{array}{r}-1.133 * * * \\
(6.490)\end{array}$ & $\begin{array}{r}- \\
0.952 * * * \\
(3.400)\end{array}$ \\
\hline Age & $\begin{array}{r}-0.501 * * * \\
(2.970) \\
\end{array}$ & $\begin{array}{r}-0.517 * * * * \\
(3.030) \\
\end{array}$ & $\begin{array}{r}-0.500 * * * \\
(2.960) \\
\end{array}$ & $\begin{array}{r}-1.011 * * * \\
(3.960) \\
\end{array}$ & $\begin{array}{r}-0.625 * * * \\
(3.320) \\
\end{array}$ & $\begin{array}{r}0.091 \\
(0.200) \\
\end{array}$ \\
\hline Leverage & $\begin{array}{r}0.019 * * * \\
(3.080)\end{array}$ & $\begin{array}{r}0.017 * * * \\
(2.790)\end{array}$ & $\begin{array}{r}0.019 * * * \\
(3.060)\end{array}$ & $\begin{array}{r}0.020 * * \\
(2.050)\end{array}$ & $\begin{array}{r}0.018 * * \\
(2.560)\end{array}$ & $\begin{array}{r}0.022 \\
(1.240)\end{array}$ \\
\hline Growth opp. & $\begin{array}{r}0.096 \\
(0.810)\end{array}$ & $\begin{array}{r}0.088 \\
(0.740)\end{array}$ & $\begin{array}{r}0.096 \\
(0.810)\end{array}$ & $\begin{array}{r}0.150 \\
(0.810)\end{array}$ & $\begin{array}{r}0.106 \\
(0.740)\end{array}$ & $\begin{array}{r}0.218 \\
(0.810)\end{array}$ \\
\hline Export & $\begin{array}{r}0.019 * * * \\
(3.180)\end{array}$ & $\begin{array}{r}0.020 * * * \\
(3.330)\end{array}$ & $\begin{array}{r}0.019 * * * \\
(3.210)\end{array}$ & $\begin{array}{r}0.013 \\
(1.530)\end{array}$ & $\begin{array}{r}0.016^{* *} \\
(2.330)\end{array}$ & $\begin{array}{r}0.038 * * * \\
(3.190)\end{array}$ \\
\hline Number of sites & $\begin{array}{r}-0.007 \\
(0.290)\end{array}$ & $\begin{array}{r}-0.012 \\
(0.530)\end{array}$ & $\begin{array}{r}-0.008 \\
(0.340)\end{array}$ & $\begin{array}{r}-0.058 \\
(1.160)\end{array}$ & $\begin{array}{r}-0.029 \\
(0.970)\end{array}$ & $\begin{array}{r}0.007 \\
(0.180)\end{array}$ \\
\hline Family business & $\begin{array}{r}-0.169 \\
(0.750)\end{array}$ & $\begin{array}{r}-0.201 \\
(0.890)\end{array}$ & $\begin{array}{r}-0.186 \\
(0.820)\end{array}$ & $\begin{array}{r}-0.297 \\
(0.850)\end{array}$ & $\begin{array}{r}-0.426 \\
(1.590)\end{array}$ & $\begin{array}{r}0.560 \\
(1.240)\end{array}$ \\
\hline Female manager & $\begin{array}{r}-0.367 \\
(1.170)\end{array}$ & $\begin{array}{r}-0.325 \\
(1.020)\end{array}$ & $\begin{array}{r}-0.311 \\
(0.990)\end{array}$ & $\begin{array}{r}-0.073 \\
(0.110)\end{array}$ & $\begin{array}{r}-0.536 \\
(1.420)\end{array}$ & $\begin{array}{r}0.260 \\
(0.430)\end{array}$ \\
\hline $\begin{array}{l}\text { Incorporated } \\
\text { company }\end{array}$ & $\begin{array}{r}0.692 * * \\
(2.560)\end{array}$ & $\begin{array}{r}0.676^{* * *} \\
(2.450)\end{array}$ & $\begin{array}{r}0.719 * * * \\
(2.690)\end{array}$ & $\begin{array}{r}0.487 \\
(1.200)\end{array}$ & $\begin{array}{c}0.568^{*} \\
(1.850)\end{array}$ & $\begin{array}{r}1.331^{* * *} \\
(2.060)\end{array}$ \\
\hline Subsidiary & $\begin{array}{r}0.255 \\
(1.040) \\
\end{array}$ & $\begin{array}{r}0.293 \\
(1.180) \\
\end{array}$ & $\begin{array}{r}0.242 \\
(0.980) \\
\end{array}$ & $\begin{array}{r}0.232 \\
(0.590) \\
\end{array}$ & $\begin{array}{r}0.133 \\
(0.460) \\
\end{array}$ & $\begin{array}{r}0.832 \\
(1.590) \\
\end{array}$ \\
\hline Fisher test & $8.76^{* * *}$ & $9.82 * * *$ & $10.28 * * *$ & $5.80^{* * * *}$ & $8.31 * * *$ & $2.83 * *$ \\
\hline Adj.R2 & 0.155 & 0.144 & 0.153 & 0.168 & 0.163 & 0.108 \\
\hline Nb. obs. & 1114 & 1114 & 1114 & 500 & 844 & 270 \\
\hline
\end{tabular}

Table 3 reports regression estimations of equation 2. In column 1,2 and 3, we use the full sample. In column 4, we focus on the subgroup of firms working with only one bank. In column 5, estimations focus on the subgroup of firms working with fewer than three banks ( 1 or 2 ). In column 6, we focus on firms working with more than two banks (3 and more). Student t-statistics are reported in brackets. $* * *, * *$ and $*$ denote statistical significance at $1 \%, 5 \%$ and $10 \%$, respectively.

On the whole, the findings contribute to a better understanding of corporate governance problems in the SME context, specifically. Banking relationship configuration shapes the intensity of bank monitoring activity. Thus, it outlines bank ability to influence the risk-taking behavior of SMEs. The results also add to the financial intermediation literature, focusing on the bank coordination process in financing SMEs and its consequences in terms of credit risk. Finally, the findings contribute to the entrepreneurial finance literature, offering insights for managers on how to handle banking relationships when conducting risky projects. 


\section{References}

Acharya, V., Amihud, Y. and Litov, L. (2011) Creditor rights and corporate risk-taking, Journal of Financial Economics, 102 (1), 150-166.

Adams, R. B., Almeida, H. and Ferriera, D. (2005) Powerfull CEOs and their impact on corporate performance, The Review of Financial Studies, 18 (4), 1403-1432.

Benkraiem, R. (2014) Small business investment sensitivity of debt before and during the global crisis, Economics Bulletin, 34 (2), 1185-1196.

Bennardo, A., Pagano, M. and Piccolo, S. (2015) Multiple bank lending, creditor rights and information sharing, The Review of Finance, 19 (2), 519-570.

Boot, A. (2000) Relationship banking: What do we know?, Journal of Financial Intermediation, 9 (1), 7-25.

Boubaker, S., Nguyen, P. and Rouatbi, W. (2012) Large shareholders and firm risk-taking behavior, Financial Markets and Corporate Governance Conference.

Bris, A. and Welsh, I. (2005) The optimal concentration of creditors, Journal of Finance, 60 (5), 2193-2212.

Carletti, E. (2004) The structure of relationship lending, endogenous monitoring and loan rates, Journal of Financial Intermediation, 13 (1), 58-86.

Cheng, S. (2008) Board size and variability of corporate performance, Journal of Financial Economics, 87 (1), 157-176.

Fluet, C. and Garellea, P. (2014) Debt rescheduling with multiple lenders: Relying on the information of others, Economica, 81 (324), 698-720.

Glejser, H. (1969) A New Test for heteroscedasticity, Journal of American Statistical Association, 64 (325), 316-323.

Himmelberg, C., Hubbard, G. and Palia, D. (1999) Understanding the determinants of managerial ownership and the link between ownership and performance, Journal of Financial Economics, 53 (3), 353-384.

Morck, R., Shleifer, A., and Vishny, R. (1988) Management ownership and market valuation: An empirical analysis, Journal of Financial Economics, 20, 293-315.

Yermarck, D. (1996) Higher market valuation of companies with a small board of directors, Journal of Financial Economics, 40 (2), 185-211. 


\section{Appendix A}

\section{Variable definitions}

\begin{tabular}{|c|c|c|}
\hline Variable Name & Definition & $\begin{array}{l}\text { Expected } \\
\text { relationship }\end{array}$ \\
\hline ROA & Operating income over total assets in percentage & \\
\hline St. dev. of ROA & $\begin{array}{l}\text { Standard deviation of the firm ROA over the period } \\
(2004-2012)\end{array}$ & \\
\hline \multicolumn{3}{|c|}{ Banking relationships: } \\
\hline Nb. of banks & Firm's number of banks & $+/-$ \\
\hline Decent. main bank & $\begin{array}{l}\text { Dummy variable taking the value of } 1 \text { if the firm works } \\
\text { with a decentralize main bank, } 0 \text { otherwise }\end{array}$ & - \\
\hline \multicolumn{3}{|c|}{ Corporate financial characteristics: } \\
\hline Size & Logarithm of total assets & - \\
\hline Age & Logarithm of firm's age & - \\
\hline Leverage & Total debt to total assets in percentage & $+/-$ \\
\hline $\begin{array}{l}\text { Growth } \\
\text { opportunities }\end{array}$ & Capital expenditure (Capex) to sales ratio & + \\
\hline \multicolumn{3}{|c|}{ Geographical diversification: } \\
\hline Export & Export over total sales & + \\
\hline Number of sec. sites & The number of secondary sites & - \\
\hline \multicolumn{3}{|c|}{ Corporate governance: } \\
\hline Family business & $\begin{array}{l}\text { Dummy variable taking the value of } 1 \text { if the firm is a } \\
\text { family business, } 0 \text { otherwise }\end{array}$ & - \\
\hline Female CEO & $\begin{array}{l}\text { Dummy variable taking the value of } 1 \text { if the firm CEO is } \\
\text { female, } 0 \text { otherwise }\end{array}$ & - \\
\hline $\begin{array}{l}\text { Incorporated } \\
\text { business }\end{array}$ & $\begin{array}{l}\text { Dummy variable taking the value of } 1 \text { if the firm is a } \\
\text { corporation, } 0 \text { otherwise }\end{array}$ & + \\
\hline Subsidiary & $\begin{array}{l}\text { Dummy variable taking the value of } 1 \text { if the firm } \\
\text { belongs to a group, } 0 \text { otherwise }\end{array}$ & + \\
\hline
\end{tabular}

